\title{
Legal and Institutional Frameworks Regulating Rural Land Governance in Ethiopia: Towards a Comparative Analysis on the Best Practices of Other African Countries
}

\author{
Temesgen Solomon Wabelo \\ School of Law, Wolaita Sodo University, Wolaita Sodo, Ethiopia \\ Email: temesgensolomon1@gmail.com
}

How to cite this paper: Wabelo, T. S. (2020). Legal and Institutional Frameworks Regulating Rural Land Governance in Ethiopia: Towards a Comparative Analysis on the Best Practices of Other African Countries. Beijing Law Review, 11, 64-98. https://doi.org/10.4236/blr.2020.111005

Received: October 18, 2019

Accepted: January 10, 2020

Published: January 13, 2020

Copyright ( 2020 by author(s) and Scientific Research Publishing Inc. This work is licensed under the Creative Commons Attribution International License (CC BY 4.0).

http://creativecommons.org/licenses/by/4.0/

(c) (i) Open Access

\begin{abstract}
This piece of writing has investigated the legal and institutional frameworks regulating rural land governance in Ethiopia by taking the comparative analysis of rural land governance of other African countries, namely Ghana, Kenya and Uganda. The best experience of these countries on the legal and institutional frameworks is examined so as to draw a lesson for the Ethiopian land governance system. The article has employed doctrinal legal research approach and rural land legislations of the country were investigated in great detail. The article has also comparative aspect because, it has drawn lessons from the legal regimes of other African countries that have best experience on the legal and institutional frameworks governing rural lands. Ethiopia can draw many good practices from Ghanaian, Kenyan and Ugandan rural land governance. Rural land legislations in these countries have given sufficient room for the protection of customary land rights and these rights are equally compensated at the time of compulsory acquisition of land use rights. In addition to these, land legislations in these countries compensate owners not only for the value of the produce upon their land but also for the market value of the land taken, cost of disturbance and other damage like severance and injurious affection. So, this can be a good lesson for Ethiopia in order to consider the life of individuals whose land is being expropriated but unable to rehabilitate to their past economic situation after compulsory acquisition. Ethiopia can also acquire a good lesson from these countries on the mode of institutional arrangement governing rural land administration is concerned. In all these African countries, the mandate to administer land is arranged at the ministry level at the apex and there are also other independent sector based institutions up to the lowest administrative hierarchy. Ethiopia, that
\end{abstract}


governs land at the directorate level under the Ministry of Agriculture at the top and bureau of land and environmental protection at the middle and land and environmental protection offices/departments at the lower administrative level can capture this good practice from Ghana, Kenya and Uganda in order to give sufficient room for this vital economic resource that is livelihood for mass populations of the country.

\section{Keywords}

Land, Land Tenure, Land Governance, Land Administration, Institutions, Ethiopia

"Land use policy is at the heart of all development endeavors that aim to bring about economic transformation. Our success in achieving the transformation depends on the effective use of our land according to its potential." H.E. Former Prime Minister Hailemariam Desalegn, at a high-level meeting held at his office on national land use policy on June 9, 2016.

\section{Introduction}

Land is increasingly recognized as a significant governance concern and it is also the single greatest resource in most countries (FAO, 2009). Peoples require land and other related resources such as forests and water for the production of food to sustain their basic livelihoods at large. Land provides a place for housing and cities, and is a basic factor of economic production as well as a basis for social, cultural and religious values and practices. Access to land and other natural resources and the associated security of tenure have significant implications for development (FAO, 2009). Land is a key for life with dignity; it is a basis for entitlements which can ensure an adequate standard of living and economic independence and thus, personal freedom (Eide, 2006). Land has major implications for human rights such as: the right to food, health, housing, work and education (Eide, 2006).

Ethiopia is predominantly an agrarian state and as in any other states inhibited by agrarian society, land in Ethiopia has been the major means of production and livelihoods. Land is the major asset in both traditional and modern societies (Ethiopian Economic Association \& Ethiopian Economic Policy Research Institute, 2002). It has been crucial means of production for the rural society and for the ruling elite (Ege, 1994). Land served the people as its abode; as means of production and symbol of freedom (Ethiopian Economic Association \& Ethiopian Economic Policy Research Institute, 2002). Land was taken as a symbol of freedom because in the pre-1974 revolutionary Ethiopia; only those people with land use right or rist land were considered as a liberated or free. People without rist land, on the other hand were considered either as slaves or serfs for land owners. For rulers of the country, land has been the basis of their political and 
economic power. Land was/is equally important to the ruling elite as political instrument to manipulate people (Olika, 2006).

The way that land is governed and administered therefore has a significant impact on the livelihood of mass inhabitants of the country. Land laws and the institutions that govern access and use of land can have great impact on the economic growth of the country. Effective land laws and well-functioning institutions that govern rural lands are highly imperative so as to regulate rights in land. These are crucial to have reputable governance on land sector and reputable governance on land in turn can ensure the rights of landholders in land. In line to this, the article has examined the legal and institutional frameworks regulating rural land governance in Ethiopia by taking the comparative analysis of other African countries (i.e. Ghana, Kenya and Uganda) that are assumed having best platform on the construction of legal and institutional frameworks regulating rural land.

\section{Brief Overview of Land Governance}

There is no one and single agreed definition that precisely connotes the term land governance. The following working definition can be crafted for land governance is concerned. Land governance concerns the rules, processes and structures through which decisions are made about access to land and its use, the way the decisions are implemented and enforced, the way that competing interests in land are managed (FAO, 2009). It includes state structures such as land agencies, courts, and ministries and municipalities responsible for land. It also covers the legal and policy framework for land, as well as traditional practices governing land transactions, inheritance and dispute resolution systems (FAO, 2009). Some of the key elements embedded in the above definitions concerning land governance are:

In the first place, Land governance emphasis on rules and process: Land governance refers to the rules and the structures that govern and mediate relationships, decision-making and enforcement of the decisions made on land. The rules and structures of land tenure can be formal (i.e. Laws, regulations, and byelaws administered by parliaments, courts and municipal councils) as well as informal or customary (e.g. elder's councils, social networks, etc.) or a combination of them. Process here defines how issues on land are put on the agenda, how decisions are made and by whom, how those decisions are implemented, and how differences and grievances on land are managed.

In the Second place, Land governance encompasses institutions: Land governance recognizes statutory as well as informal/extra-legal institutions and organisations. Land governance is conceptually broader and includes state actors, customary/non-state actors, religious sectors and private and professional sectors as well.

What all the above assertions exemplify is that, land governance is broad and encompasses many stipulations within it. It is not easy to demarcate the term in one and single terminology. But in a simplified terms, we can delineate land gov- 
ernance as a process by which decisions are made regarding access to and use of land, the manner in which those decisions are implemented and the way that conflicting interests in land are reconciled.

\section{Legal Frameworks Regulating Rural Land Governance in Ethiopia}

\subsection{Legal Regimes of Land Governance at the Federal State Level}

1) The 1995 Federal Democratic Republic of Ethiopia (FDRE) Constitution

The Ethiopia's legal framework on rural land administration comprises the constitution and other subsequent land laws enacted by the federal and regional states. The Federal Democratic Republic of Ethiopia (FDRE) Constitution has established a non-flexible land policy in the country. The constitution has paved the way for developments of land administration legal frameworks at federal and regional levels. This constitution states that, federal government shall enact laws for the utilization and conservation of land and other natural resources (Article 51 (5) of FDRE Constitution, 1995). It affirms that, the right of ownership of rural and urban land as well as all natural resources is exclusively vested in the state and the peoples of Ethiopia. Land is a common property of the Nations, Nationalities and Peoples of Ethiopia and shall not be subject to sale or to other means of exchange (Article 40 (3) of FDRE Constitution, 1995). Interestingly, the constitution also recognizes the right of peasants to obtain land without payment and the protection against eviction from their possession. Pastoralists have the right to free land for grazing and cultivation and the right not to be displaced from their own land (Article 40 (4) (5) of FDRE Constitution, 1995). In essence, the constitution has not incorporated provision concerning acquisition and transfer of land by urban dwellers. However, some interpret article 40 (6) which deals with the "right of investors" to get land, as one that includes urban dwellers as well. Article 40 (6) of the constitution envisages that, private investors may get land on the basis of payment arrangement. Here in a plain term, an investor is a person who uses the land for business activities and his/her main motive is to obtain profit. In actual fact, correlating urban dwellers with investor is erroneous because the motive of most of the urban dwellers is not profit like investor. Noticing this problem, some regional state (i.e. Amhara regional state) constitution replaced the word "investor" with "proprietor" (Article 40 (6) of Amhara Regional State Constitution, 2001). Urban dwellers/residents will be included in this change because the word proprietor may also include any person who owns a property.

2) The Federal Rural Land Administration and Use Proclamation No. 456/2005

The FDRE constitution states that, federal government shall enact laws for the utilization and conservation of land and other natural resources (Article 51 (5) of FDRE Constitution, 1995). Due to this stipulation the first federal framework legislation enacted to implement the constitution was, the federal rural land ad- 
ministration proclamation No. 89/1997 but this proclamation was repealed and replaced by the rural land administration and use proclamation No. 456/2005. Proclamation No. 456/2005 is the governing law that regulates rural land administration in the current time. While prohibiting land sale and collateralization, the proclamation permits limited land leasing (rental arrangements) and inheritance rights to be exercised, and also limited forced land distribution only to irrigation development (Article 8 (1) (5) \& Article 9 (2) of Proc. No. 456/2005, 2005). This proclamation was enacted for the purpose of ensuring tenure security; strengthening property rights of farmers; sustainably conserving and developing natural resources; establishing a land data base and conducive land administration in the country (Preamble of Proc. No. 456/2005, 2005).

3) The Expropriation of Landholdings for Public Purposes and Payment of Compensation Proclamation No. 455/2005

Another federal legislation enacted to govern rural land administration is a proclamation to provide for the Expropriation of Landholdings for Public Purposes and Payment of Compensation Proclamation, Proc. No. 455/2005. This proclamation mandates woreda or urban administrations upon advance payment of compensation; the power to expropriate rural or urban landholdings for public purpose where it believes that it should be used for a better development project to be carried out by public entities, private investors, cooperative societies or other organs, or where such expropriation has been decided by the appropriate higher regional or federal government organ for the same purpose (Article 1 of Proclamation No. 455/2005, 2005).

Recently, proclamation No. 455/2005 is repealed and replaced by another proclamation which is cited as, "Expropriation of Land Holdings for Public Purposes, Payments of Compensation and Resettlement of Displaced People Proclamation No. 1161/2019". As it is provided under article 3 of this proclamation, it shall apply throughout the country in rural and urban centers in matters relating to land expropriation; payment of compensation; and resettlement of displaced people. The proclamation is applicable within the whole federations but under article 26 (2) of it, mandates the regional states or Addis Ababa or Dire Dawa city administrations in order to issue directives necessary for the proper implementation of this proclamation and regulation issued by the council of ministers.

This proclamation has incorporated many modifications compared with the previous proclamation No. 455/2005. For example, as to proclamation No. 455/2005, the amount of compensation for property situated on the expropriated land shall be determined on the basis of replacement cost of the property. This is to mean that if the property being expropriated is used for ten years before it was taken for the public purpose then the expropriating authority would pay compensation for that specific property whose standard is at that specific time but not to erect the new one. But proclamation No. 1161/2019 replaced this provision with a new inclusion as; "The amount of compensation for the property on the land shall 
able to cover the cost of replacing the property a new" (Article 12 (2) of Proclamation No. 1161/2019, 2019). This provision has reduced the defect and ambiguity that was made by the proclamation No. 455/2005.

Another new incorporation in the new proclamation is pertaining to, displacement compensation paid for rural landholders who are permanently displaced from their holding. When we consult proclamation No. 455/2005, "A rural landholder whose landholding has been permanently expropriated shall be paid displacement compensation which shall be equivalent to ten times the average annual income he secured during the five years preceding the expropriation of the land" (Article 8 of Proclamation No. 455/2005, 2005). But proclamation No. 1161/2019 replaced this provision as, where equivalent substitute land is not available, the land holder shall be paid displacement compensation which is equivalent to fifteen times the highest annual income he generated during the last three years preceding the expropriation of the land (Article 13 (1) (b\&c) of Proclamation No. 1161/2019, 2019). Here proclamation No. 1161/2019 increased the time that displacement compensation calculated to fifteen years which was only ten years in the previous proclamation.

But the author of this article believes that the time fixed, (ten and/or fifteen years) in the previous and current proclamations is not justifiable calculation. On one hand, Land legislations in the country provide peasant farmers, semipastoralists and pastoralists to use rural land for unlimited period of time. In addition, these legislations mandates them even the right to transfer such use right to their family members. In relation to this, the method of calculating displacement compensation in both of the repealed and the current compensation payment proclamations has no any reasonable justification. Since, land legislations mandate landholders to use their holding for unlimited period of time then the displacement compensation that landholders may get by multiplying the average annual income of the previous five years by ten years in the previous proclamation No. 455/2005 and displacement compensation that is calculated by multiplying the highest annual income of the last three years by fifteen times in the current proclamation No. 1161/2019 is not justifiable one. One cannot provide legal ground to justify the displacement calculation formula in the previous and current compensation payment proclamations.

Another notable inclusion in the new proclamation which is not incorporated in the previous one is displacement compensation for communal landholding. Proclamation No. 1161/2019 obliges Regional States, Addis Ababa, and Dire Dawa city administrations in order to issue directive and determine displacement compensation for communal landholding. The proclamation provides that, valuation of displacement compensation for communal landholding shall be based on the use of the communal land; or the lost benefits and livelihood of the displaced people (Article 13 (3a) of Proclamation No. 1161/2019, 2019).

A further remarkable and interesting enclosure in the proclamation No. $1161 / 2019$ is a provision that mandates regional states, Addis Ababa and Dire 
Dawa city administrations to establish fund for compensation payment and rehabilitation (Article 16 (1) of Proclamation No. 1161/2019, 2019). The proclamation obliges regional states, Addis Ababa, and Dire Dawa city administrations in order to develop resettlement packages that may enable displaced people to sustainably resettle (Article 16 (2) of Proclamation No. 1161/2019, 2019). The proclamation also compels urban or woreda administrations the duty to resettle people displaced on the basis of the resettlement package and allocated budget (Article 16 (3) of Proclamation No. 1161/2019, 2019). If the land expropriation for public purpose is for investment, people who are displaced may own shares from the investment (Article 16 (4) of Proclamation No. 1161/2019, 2019). People who are displaced from urban or rural areas and who lost their income as a consequence of land expropriation for public purpose and who don't own shares from the investment shall be beneficiaries of the resettlement package (Article 16 (5) of Proclamation No. 1161/2019, 2019). This is one of the most promising provisions of the proclamation if the regulation that determines the contents and detail implementation of the resettlement package is enacted and should come in to force on the ground in line with the proclamation.

\subsection{Legal Regimes of Rural Land Governance at the Regional States Level}

The FDRE constitution mandates regional states with the power to administer land and other natural resources in accordance with the federal laws (Article 52 (2d) of FDRE Constitution, 1995). In line to this, Federal rural land administration and use proclamation bestows regional states the power to enact rural land administration and use laws and establish institutions so as to implement the proc. No. 456/2005 within their respective regions (Article 17 (1) (2) of Proclamation No. 456/2005, 2005). Due to this stipulation, Oromia national regional state currently enacted proclamation No. 130/2007 but the region first issued rural land administration and use proclamation in 2002 but amended in 2007; Amhara national regional state has enacted proclamation No. 133/2006 (first issued in 2000, amended in 2006); Southern Nation Nationalities and Peoples Region (SNNPR) state enacted currently working proclamation No. 110/2007 (first issued in 2003, amended in 2007); and Tigray national regional state recently enacted proclamation No. 239/2014 (first issued in 1997, amended 2002, 2007 and 2014).

What makes most of these rural land proclamations (i.e. proclamations of the Oromia, Amhara, SNNPR and Tigray regional states) similar is that, the legislations mainly focus on farmers or peasants and a few provisions concerning pastoralists and agro-pastoralists are incorporated. Provisions concerning pastoralists and agro-pastoralists are either scattered or only scanty provisions are incorporated in the legislations. So, one can conclude that rural land administration proclamations in the high land regional states of Ethiopia lacks a focus on land rights of pastoralists and semi-pastoralists. 
The other lowland regional states have also enacted their own rural land administration and use proclamations. In relation to this, Afar regional state has enacted proclamation No. 49/2009, Benishangul Gumuz regional state has enacted proclamation No. 85/2010, Gambela regional state has enacted proclamation No. 185/2011, and lastly the Somali regional state has enacted proclamation No. 128/2013.

In fact, the regional states have not added any new thing while enacting their own land legislations rather the proclamations are an exact replica of those of the federal government. None of them has attempted to contextualize the federal proclamations to the socio-economic and agro-ecological conditions of their respective regional states. Thus, the effort to formulate regional land related proclamations adds little value to the agro-pastoral development agendas. The proclamations do not give a complete picture of land use and management issues of the pastoralists and agro-pastoralists in the region.

But some lowland regional states proclamations have incorporated some additions which are not covered by the land proclamations of the other lowland regional states. If one considers the rural land proclamation of the Afar and Somali regional states, much attention is given for pastoralism and semi-pastoralism. In their preambles, these legislations emphasize the need to strengthen the right of pastoralists, agro-pastoralists and farmers; create a sense of ownership; ensure equal rights of women and the disabled; create a conducive atmosphere for investment; establish a system of rural land administration that promotes the conservation and management of natural resources in which the present use does not compromise the development endeavors of future generations; and establish a database system for different types of land holdings. The rural land administration and use proclamation of the Somali regional state guarantees the use of rural land use rights of pastoralists by ensuring that all men and women pastoralists have a right to access grazing land and use it for unlimited time (Article 5 (1) of Somali Regional State Rural Land Administration and Use Proc. No. $128 / 2013,2013)$. When we see the land proclamation in the Benishangul-Gumuz national regional state, it does not mention pastoralists or agro-pastoralists specifically rather it provides provisions relating to communal holding; but it is not clear whether this phrase addresses the issue of land use and management in pastoral and agro-pastoral areas.

Though regional states in the lowland (pastoral) areas have enacted their own land proclamations, impliedly it is the federal government that is administering land in these areas. Most of the lands in the lowland regions are grabbed by foreign direct investments. In these areas, federal government is mandated to administer investment lands if the amount of land given for the investor is more than 5000 hectare. Even if, the regional states in the lowland regions have enacted rural land administration and use laws but their administrative power is snatched by the federal government since most of these regions are occupied by foreign direct investments. 


\section{Institutional Frameworks Regulating Rural Land Governance in Ethiopia}

\subsection{Land Administration Institutions at the Federal State Level}

Institutional setup is one of the most important factors that contribute to the success of land administration systems through transforming legal tools and policies into practice. It is believed that, institutional mandates shall emanate from legal provisions. In the Ethiopian legal system, the division of power between the federal government and the regional states is asserted by the 1995 FDRE constitution. The constitution has mandated the federal government in order to enact laws for utilization and conservation of land and other natural resources (Article 51 (5) of FDRE Constitution, 1995). On the other hand, the constitution mandates regional states with the power to administer land and other natural resources in accordance with the federal laws (Article 52 (2d) of FDRE Constitution, 1995). From these constitutional provisions what we can deduce is that, the two tiers of governments (i.e. the federal and regional governments) have different functions as far as the land administration task is concerned. Here, the federal governments are entrusted with enacting framework legislation, while the regional governments are mandated with the administration and use of land as per the framework legislation of the federal government.

At the federal government level, ministry of agriculture is mandated to oversee the rural land sector. Recently federal land administration and use directorate was established in 2009 under the Ministry of agriculture to accomplish matters of coordinating the regional government and furnish necessary support to the regions (Behailu, 2015a). Land administration \& use directorate is responsible for overseeing land use and land tenure of rural lands outside large scale agricultural investment lands. The directorate among others is responsible to follow-up the implementation of rural land administration and uses proclamation No. 456/2005; provide professional support to the regional rural land administration institutions; coordinating competent authorities working on land related issues; create and facilitate information exchange between regions and contribute on capacity development of the regional institutions; links the work at the federal level with that at the regional level; and provides inputs for policy making to advance the harmonization of rural land administration in Ethiopia (Hailu, 2016).

Under the Ministry of agriculture (MoA), there is a newly established semiautonomous agency to administer large scale agricultural investment lands, which is called agricultural investment land administration agency. Ministry of agriculture through this agency is authorized to administer any large scale land deal in the country where the land size given for investor through lease arrangement is more than five thousand hectares. Accordingly, regional states are not allowed to conduct land deals with any investor if the land size meant for investment is more than 5000 hectares. For example, the contract concluded with the Ministry of agriculture (MoA) and an Indian company (karuturi Agro-products 
plc.) is a typical example that waives the states mandate not to administer land within their respective regions. The contract was signed between MoA and $\mathrm{ka}$ ruturi Agro-products plc in 25th October 2010 for fifty years at 20 birr rent (approximately one US\$) per hectare per annum. The lease contract is signed for hundred thousand hectare of land with the condition that another two hundred thousand hectare of land will be added as the company develops the presently agreed upon land within two years of the execution of the contract (Behailu, 2015b). The reason given to grant such power to the federal government is inefficiency and incompetence on the part of the regional states. The regional states were accused of inefficiency and corruption by the federal government (Behailu, 2015b). Basically, such mandate given for the federal ministry of agriculture on regional lands is against constitutional stipulation that authorizes regional state to administer land and other natural resources in accordance with federal laws within their respective regions.

\subsection{Land Administration Institutions at the Regional States Level}

The federal rural land administration and use proclamation No. 456/2005 provides a general framework for regional states so as to enact their own rural land administration and use laws and establish institutions based up on their regional conditions (Article 17 (1) of Proclamation No. 456/2005). At the present day, most of the regional states have enacted their own regional land administration and use laws and established land administration institutions based on the framework legislation. At the regional level, institutional structures vary and each regional state has adopted different approach to their land administration institution structures. In line to this, from the four highland regional states in the country, (i.e. Oromia, Amhara, SNNPR and Tigray) the three regions (Amhara, Oromia, and SNNPR) have established a separate land administration and use authority but Tigray regional state does not have a land administration department but the region has retained the same structure as the federal government ministry department (USAID, 2004).

In the Oromia national regional state, the land administration institution is structured at the bureau level as the "Oromia Bureau of rural Land and Environmental Protection” by a Proclamation No. 147/2009 (Proclamation No. 147/2009, 2009). The proclamation entrusts the bureau to formulate policies and strategies pertinent to land and the environmental protection, administer the land resources of the region, conduct studies, and prepare land use master plans, undertake cadastral surveying, and conduct studies on development corridors and growth centers (Article 5 (1-5) of Proc. No. 147/2009). Moreover, the bureau is mandated to determine the issue of compensation during expropriation of land for development works. It is also supposed to resolve or cause to be resolved by concerned organ land disputes and take legal action on individuals or entities that use land to the determent of natural resources; regulate and follow up the development of environmental impact assessment; collect, store, analyze 
and administer land resource; undertake environmental auditing; and prepare environmental standards (Article 5 (9) (13) (15) (16) of Proc. No. 147/2009).

Here what we can infer is that, the bureau is endowed with both administrative and judicial functions which are contrary to the principle of separation of power. One can consider that, as to the doctrine of separation of powers none of the government, i.e. the legislative, executive and judicial should ever exercise the powers of the other. Nevertheless, most of the mandates entrusted for the bureau are executive functions; the proclamation has also entrusted the bureau to conduct the function or act that by its very nature is reserved for the judiciary. For example, the bureau is supposed to resolve and take legal action on individuals or entities that use land to the determent of natural resources. This function is an overlapping function of the bureau that should have to be exercised by the judiciary. Since there is no separate land tribunal reserved for land disputes in the bureau then there are no lawyers whose very duty is to resolve disputes raised by the organ and party. If there are no lawyers performing the activity of the judiciary, then it is not easy for the other experts to frame each and every disputed legal fact between the bureau and party.

In the SNNPR state, the land administration authority also includes environmental protection units like that of Oromia national regional state and it is structured as "Environmental Protection, Land Administration and Utilization Authority" by a Proclamation No. 52/2003 (SNNPRS Environmental Protection Land Administration and Utilization Authority Establishment Proc. No. 52/2003, 2003). The power and duties of the authority is dealt within its provisions and among others, the authority prepares the region's environmental laws and strategies; study and record the land use type and size and provide licenses to rural land users; enforces private investors to conduct environmental impact assessment prior to commencement of any development activities on land and carries out study and decides the uses of rural lands and as appropriate provide information to the users (Article 7 (1-4) of Proclamation No. 52/2003).

The organization of the offices at Amhara national regional state is similar to that of the Oromia and SNNPR regional State in that it includes environmental units as well; however, at the woreda level, the environmental protection office is separate and operated independently from the land administration and use department (Behailu, 2015a). In the Amhara national regional state, at the beginning the institution is structured in the authority level by a proclamation No. 47/2000. This institution is termed as Environmental Protection, Land Administration and Use Authority but in the meantime, the authority was upgraded to a bureau level by proclamation No. 176/2010 and is now termed as the Environmental Protection, Rural Land Administration and Use Bureau (Article 10 (5) of Amhara Regional State Executive Organs Re-Establishment and Determination of Their Powers and Duties Proclamation No. 176/2010, 2010). The proclamation has entrusted specific powers and duties that are performed by the bureau. Among others, the bureau shall conduct study, register and maintain the type 
and amount of rural land available in the regional state; follow up that land users take care of their land holdings; register each and every land-holding and plot and thereby issue a certificate of holding with a map as per such registration; evaluate and approve the land utilization plan of those private investors prior to the commencement of their development activities; carry out studies assisting to improve the preservation, use and development of the bio-diversity, ecological and other environmental resources; and devise mechanisms enabling to conduct environmental impact assessments (Article 18 of Proclamation No. 176/2010).

Under the regional bureau, there are zonal offices which coordinate efforts at the local woreda (district) level offices. The main tasks of the zonal offices are to coordinate districts under their jurisdiction, provide training for the district staffs, consolidate data from districts, and report to the regional bureau. At the woreda level, there are officially established desks or land administration and environmental protection units that functions both land and environmental issues.

There are also lower level institutions, i.e. kebele and sub-kebele level institutions that are mandated to perform rural land administration tasks. Some of the regional states have established land administration committee in the kebele level only while others, for example Amhara and Tigray national regional states have established the committees even in the sub-kebele levels. For example, the SNNPR state has established rural land administration and use committee at the kebele level that shall implement rural land administration and use systems by a proclamation No. 110/2007 (Article 14 (5) of SNNPRS Rural Land Administration and Use proc. No. 110/2007, 2007). In the amhara and Tigray national regional state, the committee is established in the Kebele and sub-kebele levels (Article 26 (1) of Amhara Regional State Rural Land Administration and Use Proc. No. 133/2006; Article 5 of Tigray Regional State Rural Land Administration and Use Regulation No. 85/2014). In the Amhara and Tigray national regional state, the proclamations that established the committee has also stipulated the duty and responsibilities that the committee should have to perform with regard to the implementation of the proclamation. For example in the Amhara national regional state, the committee administers the land found in the kebele, facilitates conditions for land distribution; registers and keeps the land holders of the kebele and other persons given land holding certificate; and ensures any decision that suspends or deprives the right to hold or use land (Article 27 (1) of Amhara Regional State Rural Land Administration and Use Proclamation No. 133/2006). In the Tigray national regional state, land administration and use committees are established by a separate regulation No. 85/2014. This regulation has established the committee within the kebele and sub-kebele levels and also the regulation has specified the duty and responsibilities of the committee in article 7 and 8 of the regulation. What makes the Tigray rural land administration and use regulation different from other regional states proclamations is that, it has also indicated the term office of the land administration and use committee of the kebele and sub-Kebele levels. As to this regulation, the term office of the 
committee is five years but the kebele council can re-appoint a person for second term if it believes that the person fits for the position (Article $6(1 \& 2)$ of Tigray Regional State Rural Land Administration and Use Regulation No. 85/2014). In the Tigray national regional state, there is also yet another body that is established at the kebele level (i.e. kebele rural land adjudication committee) by a proclamation No. 240/2014 (Proclamation to Provides Power and Duties of Rural Kebele Land Adjudication Committee of Tigray National Regional State Proclamation No. 240/2014, 2014). Here one may wonder the reason to have two separate committees at the kebele level. But what makes the kebele rural land adjudication committee different from land administration and use committee is that, the former is established to perform judicial functions in order to hear and resolve disputes related on rural land while the later is mandated to perform administrative function entrusted in the rural land proclamation of the region. This can be a good lesson for other regional states in Ethiopia in order to have effective rural land governance in the country by decentralizing functions between the administrative and judicial organs.

\section{Rural Land Rights in Ethiopia}

\subsection{Typologies of Rural Land Tenure in Ethiopia}

There are different conceptual definitions for the term land tenure. Somewhat inclusive definition is given by United Nations food and agriculture organization (FAO) and here it is defined as a "relationship, whether legally or customarily defined, among people, as individuals or groups, with respect to land" (FAO, 2002). As to this definition, there are three things to be noted regarding land tenure. Firstly, land tenure refers people's relationship to land. Secondly, it denotes an institution through which individuals access to land and use right is determined. Thirdly, it denotes rules of the game through which the content of rights and duties of individuals with respect to land are defined. Rules of tenure define how property rights to land are to be allocated within societies. Generally, land tenure system refers to terms and conditions under which land and other related resources on land are held and used.

Three tenure typologies are recognized in Ethiopia and these are incorporated in the federal and regional states rural land administration and use proclamations. These are the private holding, communal and state holding. Proclamation No. 456/2005 defines private holding as rural land holding of peasants, semipastoralists and pastoralists and other bodies entitled by law to use rural land (Article 2 (11) of Proclamation No. 456/2005). Under the Ethiopian legal system, private holding is a holding right with the use right of the land extended to the holders indefinitely.

The one and foremost issue that raise discussion under the private holding is the insertion of pastoral land within the private holding category. Private holding includes pastoral land tenure systems even though the way pastoral lands managed are just seems communal ones. Pastoral lands rather should be re- 
garded as "res communes" or communal lands in the proper sense, with various ownership rights vested in specific collectives of people. In the Ethiopian legal system, pastoral tenure which is one of vaguely defined rights over large tracts of land vested in a widely defined group is categorized under the agricultural tenure systems that attach specific rights over specific parcels of land to specific individuals over long periods of time. In strictly legal terms, all pastoral lands are now owned by the state on behalf of the peoples of Ethiopia. The FDRE Constitution guarantees access to land for all Ethiopian pastoralists to have the right to free land for grazing and cultivation as well as the right not to be displaced from their own lands, but leaves it to subsidiary legislation, to be worked out by the ethnically based regional states, to specify the terms and conditions under which land is made available to users. In practical terms, the pastoral lands have not been covered by specific national legislation granting security of tenure to the people who live from pastoralism. A number of issues combine to obscure the existence of tenure regimes in the pastoral areas, leading to the assumption that pastoral lands basically were "res nullius" or no-man's land. The assumption that pastoral lands do not belong to anybody has been central to one of the most enduring generalizations about pastoralism, viz. the tragedy of the commons theorem (Hardin, 1968).

The second type of tenure typology (which is vaguely recognized) in the Ethiopian legal system is communal holding. The proclamation No. 456/2005 gives definition for communal holding as, a rural land which is given by the government to local residents for common grazing, forestry and other social services (Article 2 (12) of Proclamation No. 456/2005). Thus, the land is under the custody of the community bestowed from the government for common use. The community can use the communal holding for animal grazing, growing perennials, and perhaps holding some social functions on it. A communal land by definition allows access of use to everybody who is a residing member of the community in question. It is important that an individual be a recognized member of the community in order for him or her to be beneficial of the communal land. Communal holding is designated usually from the customary use rights of the community, yet it is subject to conversion to private holding at the prerogative of the state (Behailu, 2015a).

Though the federal and regional states rural land administration and use proclamations apparently recognizes communal land tenure typology as one mode of land tenure but its existence is debatable one. Strictly speaking, the existence of communal land tenure typology highly rests up on the will of government. So, one can only claim two types land tenure regimes (i.e. the state and the private holding). From the readings of both the federal and regional states rural land administration and use proclamations, one can strike out the communal holding from the ambit of rural land tenure typology. Proclamation No. $456 / 2005$ defines communal holding as, rural land which is given by the government to local residents for common grazing, forestry and other social services. From the underlined phrase one can deduce that, the government is the pro- 
vider of communal land for the local residents. This is to mean that, if the government is not pleased to provide communal land then there is no this type of tenure typology. So, one can argue that, communal land tenure typology is statutorily abolished one and it can only exist when the government is pleases to home it. In addition, if we consult article 5 (3) of proclamation No. 456/2005, it provides that, government being the owner of rural land, communal holdings can be changed to private holdings as may be necessary. Here also the existence of the communal land rests up on the will of the government. The preamble of proclamation No. $456 / 2005$ also states one of its aims is to: encourage private investors in pastoralist areas where there is tribe based communal holding system. This provision is evident and that encourages transfer of communal land holdings to private investors. Generally, rural land laws are not in favor of a full recognition of the communal land holdings as one type of tenure typology.

The third tenure typology under the Ethiopian legal system is state holding. State holding on the other hand is defined as, a rural land demarcated and those lands to be demarcated in the future at federal or regional states holdings; and includes forest lands, wildlife protected areas, state farms, mining lands, lakes, rivers, and other rural lands (Article 2 (13) of Proclamation No. 456/2005). If a certain piece of land is not categorized under private or communal holding typology then it automatically falls under the domain of the state holding because of the phrase "... any other land" included in the wordings of the proclamation.

\subsection{Nature of Rights in Land}

In many countries the issue of land is not a matter of constitution rather it can be equally depicted under the category of property rights. Constitutional laws stipulate property rights in general rather than expressly fixing of land rights separately. In the Ethiopian legal system, the FDRE constitution while defining property rights has utilized bundles of rights approach. The inclusive concept of bundles of rights is developed by Schlager and Ostrom ${ }^{1}$ and as to the bundle of rights approach; the owners hold all five types of rights (access, withdrawal, management, exclusion, and alienation rights) (Schlager \& Ostrom, 1992). But the constitution has treated the land issue separately by isolating it from other categories of private property that fall under the bundle of rights approach. The bundle of rights approach envisaged in the constitution can be identified when one reads article 40 (1) (7) of the FDRE constitution. According to FDRE constitution, the right to ownership of private property includes the right to acquire, to use, to dispose of such property by sale or bequest or to transfer it otherwise (Article 40 (1) of FDRE Constitution). In addition to this, the constitution also provides that, every Ethiopian shall have the full right to the immovable proper${ }^{1}$ As to the bundle of rights approach of Schlager and Ostrom, owners of the property hold the right to access (right to enter a defined physical area and enjoy non-subtractive benefits); the rights to withdrawal (the right to obtain resource units or products of a resource system); the right to management (for example, to transform and use a resource); exclusion rights (that is to determine who is entitled to access and withdrawal rights, and who decides about the transfer of such entitlements); and alienation rights (the right to sell or lease a resource). 
ty he builds and to the permanent improvements he brings about on the land by his labor or capital. This right shall include the right to alienate, to bequeath, and, where the right of use expires, to remove his property, transfer his title, or claim compensation for it (Article 40 (7) of 1995 FDRE Constitution). As to these two constitutional provisions, the right to private property of holders in FDRE constitution is constructed in terms of the bundle of rights approach as categorized by Schlager and Ostrom.

Article 40 (2) of the constitution defines private property as, any tangible or intangible product which has value and is produced by the labor, creativity, enterprise or capital of an individual citizen, association which enjoy juridical personality under the law, or in appropriate circumstances, by communities specifically empowered by law to own property in common. From this sub-provision one can argue that land cannot regard as private property because there is no labor, creativity, enterprise and capital to create land. This is to mean that since there is no labor or creativity in order to make land as private property, then one cannot treat it as a property of peasants or pastoralists. So, one can believe that definition rendered by the drafters of the constitution for private property is obviously to exclude land from the ambit of private property.

The constitution has treated the land rights of holders separately by excluding it from the category of bundle of rights approach. This can be evident when one reads article 40 (3) of the constitution. As to this provision of the constitution, the right to ownership of rural and urban land, as well as of all natural resources, is exclusively vested in the State and in the peoples of Ethiopia. Land is a common property of the Nations, Nationalities and Peoples of Ethiopia and shall not be subject to sale or to other means of exchange. So, peasants and pastoralists have only use right in land and they cannot enjoy the bundle of rights approach (especially alienation rights) as dictated by Schlager and Ostrom.

The nature of rights in land provided under the FDRE constitution is also reduced in the federal and regional rural land administration and use proclamations. The proclamations affirm private ownership of land and provide farmers to have holding right only. Holding right of peasants and pastoralists under the proclamations are defined as the rights, to use rural land for purposes of agriculture and natural resource development, lease and bequeath to members of his family or other lawful heirs, and includes the right to acquire property produced on his land thereon by his labor or capital and to sale, exchange and bequeath same (Article 2 (4) of Proclamation No. 456/2005; Article 2 (6) of Proclamation No. 110/2007). The proclamations have provided peasant farmers to have all the rights in land except sale and collateralization of land.

Private holdings cannot be sold but can only be transferred through inheritance to family members practicing agriculture and living with the right holder. This is confirmed under proclamation No. 456/2005 in a manner that, any person who is member of a peasant farmer, semi-pastoralist and pastoralist family having the right to use rural land may get rural land from his family by donation 
or inheritance (Article 5 (2) of Proclamation No. 456/2005). Holdings can be leased to other farmers or investors, subject to restrictions on the extent and duration of leases. The law gives the discretion of deciding on the duration of the lease period and the amount of land to be leased out to regional governments. For example, the Oromia rural land administration and use proclamation mandates peasants, pastoralists or semi-pastoralists the right to rent out up to half of his total holding for not more than three years for those who apply traditional farming and fifteen years for mechanized farming (Article 10 (1) (2) of Oromia Rural Land Administration and Use Proclamation No. 130/2007, 2007). Tigray national regional state rural land administration and use proclamation also bestows rural land holders in order to rent out up to half of their holding for not more than three years for those who apply traditional farming and twenty years for those who apply mechanized farming (Article 9 (4) (a) (b) of Tigray Regional State Rural Land Administration and Use Proclamation No. 239/2014).

The land laws also do not allow rights in land being used as collateral for loans and this in turn restricts rural land holders not to offer their land rights for their credit loans. The governments justification provided for this is to protect rural land holders from exploitation by loan sharks and land speculators and to avoid the tide of rural to urban migration (Minutes of the Ethiopian Constituent Assembly, 1995). The government also believes that if land is owned privately and used as collateral for credit, smallholders will lose the use rights over the land they mortgaged and migrate in mass to the cities and towns. Many scholars do not agree with this and ask the question "why are investors who lease land for a limited period allowed to use their land use right as collateral while small scale landholders who have use right in perpetuity are not accorded the same privilege" (Deininger \& Jin, 2005). The justification forwarded by the government is not as such plausible because if land use right is used as collateral then one who has provided credit for the holder is not entitled to use the land use rights indefinitely rather for a period indicated in the contract of loan if the debtor has failed to furnish the debt in the agreed period of time.

\subsection{Duration of Rights in Land}

The breadth of duration of land rights is important determinant factor component to land tenure security. According to Place and others, land tenure security can be defined to exist when an individual perceives that he or she has rights to a piece of land on a continuous basis, free from imposition or interference from outside sources, as well as ability to reap benefits of labor and capital invested in the land, either in use or upon transfer of another holder (Place et al., 1993). It is assumed that breadth or robustness of those rights (such as rights of use, transfer and exclusion), duration of such rights, and assurances of such rights are important components of tenure security. Security of tenure refers to the degree of certainty that one's land rights will be recognized by others and protected in case of specific challenges. One major component of security is thus effective protec- 
tion against the arbitrary curtailment of land rights with enforceable guarantees and effective remedies against the loss of these rights. A second component is a reasonable duration of rights appropriate to the use to which the land is being put. A right to use land for a six month growing season may give a person sufficient security to invest in vegetable production, but the tenure is unlikely to be secure enough to encourage long term investments such as planting trees or building irrigation systems (FAO, 2009).

The FDRE constitution has not specifically dealt the duration of land rights rather the constitution under article 40 (5) of it states that, Ethiopian peasants have right to obtain land without payment and the protection against eviction from their possession by leaving the detail to be filled by other specific legislations. From the underlined phrase what we can deduce is that, the constitution has not fixed the duration of rights in land rather it has only guaranteed protection against eviction from the possession. The duration of rights in land is specified by other federal and regional rural land legislations. The land legislation in the federal and regional states has guaranteed peasants to have such right for life time. It has been declared that rural land use right of peasant farmers, semi-pastoralists and pastoralists shall have no time limit (Article 7 (1) of Proc. No. 456/2005; Article 5 (3) of Proc. No. 133/2006). This longer duration of time gives tenure security to the holders of the land and due to this the investments made thereon will not be threatened by time limitation.

The proclamation No. 456/2005 also construes the duration of rural land use right of other holders to be determined by the rural land administration laws of regions (Article 7 (2) of Proclamation No. 456/2005). The duration of land rights of holders within this category is determined by taking in to account the purpose for which land is being acquired. Under this category we can categorize the land rights of investors and those land holders that access land on the basis of land rent contractual arrangement. In this case, the proclamation has opened the door for the regional states in order to fix the duration of rights in land for these specific land holders.

\subsection{Land Tenure Debates in Ethiopia: Towards Reducing the Tension}

Rural land policy has remained one of the sources of disagreement and focus of debate among politicians, academicians and other concerned parties in Ethiopia. During the transition period of the current regime, when the government had not yet defined its policy on rural land, much concern was shown by different sections of the society as well as by international agencies on the preferred policy issue on rural land. Later on, the ruling party made it clear that the policy on land was to continue more or less on the same lines to that of the derg $s$ policies: land ownership remained vested in the state and this was enshrined in the FDRE constitution. The insertion of the issue of land in the constitution, however, may indicate that rural land has increasingly become a political affair. The constitu- 
tion gives peasants and pastoralists only to have usufruct rights. The fact that farmers have only usufruct rights to land has sparked a debate among Ethiopian and foreign scholars regarding the effect of the tenure system on land investment and management, factor mobility and the development of the non-farm sector (Gebremedhin \& Nega, 2005).

An assessment of such land debate in present day Ethiopia shows that there is a focus on ownership issues and dichotomous views on the state versus private ownership regimes. Political parties, the press, scholars, donors, and other parties are involved in such debate. The current debate on the land issue focuses on ownership and heavily relies on private versus state dichotomy. State ownership of land has been strongly advocated by the ruling party while private ownership is favored by western economic advisors, international organizations like the World Bank, many opposition political parties and some other scholars as well. Ethiopian People's Revolutionary Democratic Front (EPRDF) and its top government officials repeatedly notified that, debating on constitutionally resolved issue is a sterile argument. As a response to their strong desire to make land a private property and saleable as a commodity, the late EPRDF's chairman, Melese Zenawi defended that land privatization in Ethiopia would take place only over the EPRDF's dead body (Kassahun, 2006). During his end of year report to parliament in June 2004, Meles announced that the change of land policy in Ethiopia would take place only over his party, "Ethiopian People's Democratic Revolutionary Front's tombstone" (Devereux et al., 2005).

The argument forwarded by the ruling party for the continuation of land as public/state property rests mainly on two policy objectives, i.e., these are the social equity and tenure security synthesis. The FDRE Constitution as well as other federal and regional land laws ensures the free access to agricultural land. The amount of land to be provided to peasant farmers, as far as possible, is made equal. Accordingly, the policy objective is to ensure equality of citizens in accessing the land. However, the weakness of this policy objective is that in the first place, it does not address the urban land rather article 40 of the FDRE constitution only deals rural land issue; Second, it is argued that since there is lack of arable land in the highlands of the country, equality of access to land is ensured through transfer of land from large holders to small holders or through land redistribution not by inserting the land policy within the constitution.

Tenure security is the other policy objective of the state to make land under the public/state ownership. State ownership of land is considered to be the best mechanism to protect the peasants against market forces. In particular, it has been argued that private ownership of rural land would lead to massive eviction or migration of the farming population, as poor farmers would be forced to sell their plots to unscrupulous urban speculators, particularly during periods of hardship (MOIPAD, 2001). Most of the farmers who live in the highland areas where there is scarcity of land but large amount of accumulated human power due to high population density. Allowing the farmer to sell land here, would lead 
either to displacing the farmers or converting them to tenants (MOIPAD, 2001). Those pro-state ownership (mainly the ruling party) argue that private ownership will lead to concentration of land in the hands of a few who have the ability to buy, to eviction of the poor peasants, landlessness, and rural to urban migration of the same peasants who are left without any alternative means of livelihood.

But this argument of the government that supports state ownership of land is criticized by scholars and other donor institutions because of lack of supportive evidence. They question the validity of the government's argument that smallholders will lose their use rights if they sell their holding and migrate in mass to the cities. Many findings of the studies show that, great majority of rural land holders are smart enough not to gamble with their future of their families' livelihood even if private ownership is provided within the constitution. The countrywide survey conducted by the Ethiopian Economic Policy Research Institute found out that only $4.5 \%$ of landholders are willing to sell their land if given the opportunity and $90 \%$ indicated that they will not consider selling whole or part of their holdings (Ethiopian Economic Association \& Ethiopian Economic Policy Research Institute, 2002).

In their struggle for private ownership, the issue of land sale is invariably taken by economists and western oriented advisors as a central agenda. They criticize the states effort to move towards market economy while controlling land. They contend that, one cannot move towards a market economy while keeping land, the most vital means of production on agricultural economy outside the operation of the market (Bruce et al., 1994). Those who argue for privatization maintain that: In the first place, private ownership will ensure security of tenure and provide peasants with the incentives necessary to make investments and long term improvements on the land and, Secondly, one cannot move towards a market economy while keeping land; the most vital means of production in an agricultural economy outside the operation of the market (Inter-Africa Group, 1992). The only way peasant's confidence will be restored and insecurity of tenure abolished thus enabling peasants to take their land as their assets and to work it with great effort, is if peasants are assured that no one can take their land from them (Rahmato, 1992). Rahmato also underlines that, freehold is the best means of ensuring absolute tenure security. It will provide strong incentives to peasants to invest on their land, and will make land transactions easier and more efficient (Rahamato, 1994). The economic impact of such state ownership was making it difficult to the peasant to develop the productivity of the land and his labor as he has seen the land does not belong to him and that it can be taken away by the state whenever necessary (Woldemariam, 1999). The ruling party's argument that if peasants are given unrestricted land rights, then they will sell their lands and they will become landless is judged as unfounded and if it happens in extraordinary situations, it is not considered as disastrous as has been argued by those who are against it (Rahmato, 1994; Woldemariam 1999). Unnecessary restrictions may deny efficient farmer access to farmland and would 
contribute to underutilization of available land (Aredo, 1999). In a symposium on the Ethiopian economy, it was reported that there was a consensus that the current land ownership regime system has detrimental effects on agricultural productivity and natural resource conservation but, no consensus was reached as to whether or not the solution was to be found in the privatization of land (Inter-Africa Group, 1992).

In the above discussions (i.e. both those who argue state ownership regime on one hand and those who argue private ownership regime on the other hand) strictly criticizes the other side of the regime and promotes their own side only. On one hand, the contenders, on both sides of the argument, are more likely reflecting their own interest and ideologies without fully investigating the interest of the rural society. On the other hand, each of them may not fully understand the adverse effect of deciding land policies without letting the concerned sections of the society. The debate especially on the side of government even has not secured the opinions and interests of the peasants and pastoralists in order to reach their conclusion. It is for this reason that, Allan Hobben profoundly suggested that; it will be better if contending parties listen what the people say and take into account the social, cultural and historical contexts of the society before designing and revising land policies and strategies (Hobben, 2002).

The author of this article believes that, the hot debate upon a single tenure arrangement cannot resolve land related problems rather one can establish another alternative policy measures to have an effective land governance system in the country. It is not sound to seriously criticize the public ownership regimes because it has its own advantage. The most core advantage of the public policy option can be raised when the government needs the land for the development works. If land is totally controlled under the private tenure arrangement regime, it is not easy for the government to pay compensation for each and every inch of the land required for the public purpose especially in developing countries. So, public ownership regime on land cannot be totally condemned. Likewise, one cannot totally condemn private ownership regime because it is an important tool among others, to access land for the landless farmers of agrarian societies for their livelihood. The remedy to umpire the two sides of debates would come up with by utilizing different policy options taking in to consideration of the reality of one country. Here, Ethiopia can grasp the practice of Ghana and Uganda concerning the adoption alternative land use policy is concerned.

For example, in Ghana there are two types of land ownership regimes: public or state lands and private lands. Public or state lands are defined as lands compulsorily acquired by the government through the invocation of the appropriate legislation, vested in the president and held in trust by the state for the entire people of Ghana. In contrast, private lands in most parts of the country are in communal ownership, held in trust for the community or group by a stool or skin as symbol of traditional authority, or by a family. Even the vast majority of land in Ghana is occupied by the private ownership regime. Land held under 
private ownership accounts for about $80 \%$ of the land in Ghana, whereas the state owns about 20\% (Antwi \& Adams, 2003). So, fighting upon a single land policy is not as such tenable for developing countries such as Ethiopia rather it is important to have a combination of different alternative policy regimes to have effective land governance in the country.

\section{Lessons Learned From the Experiences of Other African Countries: In Response to Filling a Gap on the Rural Land Governance of Ethiopia}

This section has dealt the comparative analysis of other African countries experience namely (Ghana, Kenya and Uganda) concerning the legal and institutional framework on the rural land governance. The best experience of these countries that is assumed to fill a gap in the land governance system of Ethiopian is dealt in brief. The three countries are chosen because they are agrarian countries and that are inhabited with substantial number of smallholder population.

\section{1) Ghana}

The first African country that Ethiopia can notice a good practice on the governance of rural land is Ghana. Agriculture is the backbone of Ghana's economy. It contributes about $36 \%$ of GDP and employs approximately $70 \%$ of the rural population. The country is estimated to have 23 million hectares of land area, of which $57 \%$ is cultivable (Tiah, 2013). One of the distinguishing features of land governance in Ghana is the existence of dual (i.e. customary and statutory) recognition of land tenure arrangements. Currently, over $80 \%$ of land is considered customarily owned (Wily \& Hammond, 2001). The 1992 constitution of Ghana confirms that, all stool ${ }^{2}$ lands shall vest in the appropriate stool on behalf of and in trust for the subjects of the stool in accordance with customary law and usage (Article 267 (1) of Constitution of the Republic of Ghana, 1992). The constitution sets up the office of the administrator of stool lands and charges the office with the collection and disbursements of all stool land revenues, defined to include all rents, dues, royalties, revenues or other payments whether in the nature of income or capital from stool lands (Article 267 (2) of Constitution of the Republic of Ghana, 1992). The same constitution further confirms that, there shall be no disposition or development of any stool land unless the regional lands commission of the region in which the land is situated has certified that the disposition or development is consistent with the development plan drawn up or approved by the planning authority for the area concerned (Article 267 (3) of Constitution of the Republic of Ghana, 1992). Unless the lands commission has given the necessary certification then any disposition by the indigenous owners is invalid.

Another and the most notable incorporation of rights protection in the con-

${ }^{2}$ Stool lands are customary lands vested in a traditional chief, or other community leaders, on behalf of and in trust for the tribe (stool/skin), in accordance with customary law and usage. These lands include all those lands that are at the disposal of local communities. The heads of the groups of chiefs and councils of elders are responsible for managing the land on behalf of the Stool or Skin. 
stitution of Ghana is at the time of expropriation of land for more public purpose. The 1992 Constitution has incorporated clear provisions concerning public purpose which requires clear justification for acquisition, and provides a pre-emption right for former owners in the event land is not used for its intended public purpose. Here the state has a duty to indicate the specific use or uses to which the land is to be put before the acquisition becomes valid. Should there arise a diversion of use, the original owners have a legal basis to mount a challenge in the courts to seek the return of the land to them under a right of pre-emption (Article 20 (6) of Constitution of the Republic of Ghana, 1992). Where the property is not used in the public interest or for the purpose for which it was acquired, the owner of the property immediately before the compulsory acquisition, shall be given the first option for acquiring the property and shall, on such reacquisition refund the whole or part of the compensation paid to him as provided for by law or such other amount as is commensurate with the value of the property at the time of the reacquisition. As to the constitution, compulsory acquisition of property by the state shall only be made under a law which makes provision for: The prompt payment of fair and adequate compensation; and a right of access to the high court by any person who has an interest in or right over the property whether direct or on appeal from any other authority for the determination of his interest or right and the amount of compensation to which he is entitled (Article 20 (2) of Constitution of the Republic of Ghana, 1992). The various claims for which an expropriated owner may be compensated are: market value of the land taken; or replacement value of the land taken; and cost of disturbance; and other damage (severance and injurious affection); or grant land of equivalent value (Section 10 of Administration of Lands Act of the Republic of Ghana, 1962). Furthermore, where the compulsory acquisition of land involves the displacement of any inhabitants, the state is required to resettle them on suitable alternative land with regard to their economic wellbeing and social and cultural values (Article 20 (3) of Constitution of the Republic of Ghana, 1992).

Ghana has also good institutional structure on land governance that Ethiopia can take a lesson from it. When we see the statutory land administration institutions, the state has established a formal administrative framework consisting of a number of land sector agencies to facilitate land administration system. The main sector based institutions involved in the land administration system are the Lands commission, the office of administrator of stool lands, the land title registry, the lands valuation board and the survey department. These all institutions are structured under the ministry of land and forestry.

Ethiopia can draw a good lesson from Ghanaians land administration system. There is no separate law for the protection of customary lands and also the FDRE constitution has not expressly given the governance of land within these areas for the customary land administration institutions like that of Ghana. So with regard to customary lands, it is imperative for Ethiopia to leave customary 
lands for the customary land administration institutions or establish separate legislations that guides the administration of lands in the customary land holdings. Ethiopia can also take a good lesson from Ghana with regard to protection of rights at the time of rural expropriation is concerned. The constitution of Ghana compensates owners not only for the value of the produce upon the land but also for the market value of the land taken, cost of disturbance and other damage like severance and injurious affection. Even the constitution of Ghana obliges the state to resettle land owners on a suitable alternative land with regard to their economic wellbeing where the compulsory acquisition of land involves the displacement of inhabitants. This can be a good lesson for Ethiopia in order to consider the life of individuals whose land is expropriated but unable to rehabilitate themselves to their previous economic situation. Another lesson that Ethiopia can capture from Ghana is on the institutions that administer rural lands. There is ministry of land and forestry in Ghana that administers rural land and other additional institutions that are mandated to govern sector specific issues on land. Ethiopia that governs land under the directorate level under the ministry of agriculture can craft this good practice from Ghana in order to govern the giant economic resource for the most population of the country.

\section{2) Kenya}

Another country that Ethiopia can capture a good lesson concerning governance of rural land is Kenya. In Kenya, productive agricultural land constitutes about $20 \%$ of all lands, from which $80 \%$ of Kenyans derive their livelihoods, mostly in rural areas (Narh et al., 2016). In 2010, Kenya enacted a new Constitution that led to a policy shift in the administration of land in the country. Article 62 of the Constitution provides that, all land in Kenya belongs to the people of Kenya collectively as a nation, as communities and as individuals. The constitution has abolished state from being as the owner of rural land. Land is classified as public land, private land and community land. In order to strengthen the constitutional framework on land, the national constitution implementation commission in consultation with the Ministry of Lands began a process of drafting different legislations to be enacted by parliament in order to guide the implementation and management of each of the proposed categories of land stipulated in the constitution (Future Agricultures, 2014). Seven bills are identified for the proposed amendment and these are: the Land Bill, the Registration Bill, the Environment and Land Court Bill, the Kenya National Land Commission Bill, the Matrimonial Property Bill, the Private Land Bill and the Community Land Bill. Six of these bills have been legislated as Acts of Parliament. The notable land reform measures that these pieces of legislations have adopted are giving recognition for customary land rights. The reform has given place for the communal land to be retained within the hands of the respective communities. Further the Constitution provides for community land ${ }^{3}$ which shall vest in and

${ }^{3}$ This community land shall consist of land lawfully held in the name of group representatives; land transferred to specific communities under any law; land declared to be community land under an Act of Parliament; and community forests, grazing areas, ancestral lands and trust lands. 
be held by communities identified on the basis of ethnicity, culture or similar communities of interest (Article 63 (1) of Constitution of the Republic of Kenya, 2010). The constitution has also strongly confirmed that, community land shall not be disposed of or otherwise used except in terms of legislation specifying the nature and extent of the rights of members of each community individually and collectively (Article 63 (4) of Constitution of the Republic of Kenya, 2010). Even to give effect to this provision of the Constitution, the constitution further mandated the parliament to enact detail legislation that will operationalise the implementation of the provision (Article 63 (5) of Constitution of the Republic of Kenya, 2010). Due to this insertion, the legislator has adopted the Community Land Act of $2016^{4}$ that strongly focuses upon how community lands are regulated and governed by communities.

The land policy of Kenya also equally recognizes community land as land lawfully held, managed and used by a specific community. The National Land Policy adopted in December 2009 among others: recognizes and protects customary rights to land; outlines principles of sustainable land use and provides productivity and conservation targets and guidelines; calls for reform of land management institutions to ensure devolution of power, increased participation and representation, justice, equity, and sustainability; calls for the establishment of the National Land Commission (NLC), District Land Boards, and Community Land Boards; calls for the development of a legal and institutional framework to handle land restitution and resettlement for those who have been dispossessed; and calls for reconsideration of constitutional protection for the property rights of those who obtained their land irregularly. It equally provides for communities who have rights for using communal land to own it in perpetuity (Ministry of Land, Chapter 3 of National Land Policy of Kenya, 2009).

Another prominent reform in rural land sector in Kenya that can be a good lesson for Ethiopia is the issue of compensation of rural land at the time of expropriation. The constitution compensates not only holders that have valid land holding certificates but also occupants that hold land in good faith including customary land rights holders that may not have landholding title (Article 40 (4) of 2010 Constitution of the Republic of Kenya). By inserting this provision, the constitution has restricted the power of the government from wondering freely on communal lands in the name of investment.

Currently, the Ethiopian government has adopted an interesting move in order to protect the right of communal land holders. The new expropriation of landholdings for public purpose and payment of compensation proclamation No. 1161/2019 has gone a good move upon compensating communal land holdings. The proclamation awards the displacement compensation for communal landholdings and as to this proclamation; valuation of displacement compensation for communal landholding shall be based on the use of the communal land; or the lost benefits and livelihood of the displaced people (Article 13 (3) of Proc-

${ }^{4}$ Kenya Gazette Supplement Acts, Community Land Act (2016), Nairobi, $7^{\text {th }}$ September, 2016. 
lamation No. 1161/2019).

The reform in the institutional arrangement governing rural land in Kenya is also another pivotal aspect intended for the effective governance of rural land sector. There is a ministry of land at the federal level mandated to overrule land issues and other lower level structures are also decentralized even to the lowest administrative level hierarchy. Article 67 of the Constitution of Kenya also established the National Land Commission (NLC), which, inter alia, is endowed with the tasks to manage public land, monitor land-use planning (including exploitation of natural resources) and investigate into present and historical land injustice. The NLC holds the mandate to among others: alienate public land on behalf of national and county governments; assess all rights and interests in such land; manage and administer all unregistered trust and community land and register such land (Article 5 (2) (3) of National Land Commission Act of Kenya, 2012). Governing land at the ministry level is crucial for the effective management of land which is the livelihood for more that $80 \%$ of the country. Governing land in the ministry level is also indispensable to have adequate budget for the management of the sector and to have sufficient human resource in order to administer the sector.

\section{3) Uganda}

Another African country that has good legal and policy framework on the management of rural land and that Ethiopia can draw a lesson is Uganda. Uganda has undertaken a series of legal and policy reforms with regard to governance of rural land. The 1995 Constitution and the Land Act of 1998 redefined land rights, attempted to resolve old conflicts, and provided decentralized institutional framework for land management. The 1995 constitution of Uganda brought about fundamental reforms in ownership, tenure management and control of land in Uganda. The constitution and the Land Act provide that, land in Uganda shall belong to the citizens of Uganda and shall vest in them in accordance with four tenure arrangements: Customary, Freehold, Mailo and Leasehold (Article 237 of the 1995 Constitution of the Republic of Uganda; Section Three of the 1998 Land Act of the Republic of Uganda). By inserting this clause, the constitution has totally reversed the old system where land was vested in the public hand. The state no longer controls ownership of land in Uganda. The constitution also recognizes customary tenure as one of the forms of holding land in Uganda. Citizens owning land under customary tenure may acquire certificates of ownership in a manner prescribed by parliament; and land under customary tenure may be converted to freehold land ownership by registration (Article 237 (4) (a) (b) of 1995 Constitution of the Republic of Uganda). The same message is provided under the 1998 Land Act as; any person, family, community or association holding land under customary tenure on former public land may convert the customary tenure into freehold tenure in accordance with this Act (Section 9 of the 1998 Land Act of the Republic of Uganda). Since the majority of Ugandans hold land under customary tenure; these provisions of 
the constitution and the Land Act of 1998 therefore guarantees them security of tenure on land ownership. This certificate of customary ownership has been accorded value under the Land Act enabling it to be transferred, mortgaged, or otherwise pledged. This will enable holders of a certificate of customary ownership to have access to credit.

Another issue that highly protects land holders in Uganda that can also be a good lesson for Ethiopia is computation of compensation at the time of compulsory acquisition of land (Section 41 (6) and Section 77 of 1998 Land Act of the Republic of Uganda). Here, Uganda follows almost parallel approach with Ghana concerning payment of compensation at the time of compulsory acquisition is concerned. The 1998 Land Act provides that, any compulsory acquisition of land shall be paid at a fair market valuation assessed on a willing seller willing buyer basis. The Act also obliges the state to furnish compensation for any losses caused by severance or injurious affection and reasonable costs of disturbance. Further, in the case of land occupied under customary tenure, in addition to compensation assessed under the Act, there shall be paid as a disturbance allowance a sum not exceeding 15 percent of the sum awarded to the person from whom land is to be acquired where that person was using the land as his or her home (Section 41 (6) and Section 77 of 1998 Land Act of the Republic of Uganda).

Uganda has also adopted a mechanism so as to establish a fund known as the Land Fund that is among others meant to resettle persons who have been rendered landless by government action, natural disaster or any other cause (Section 41 of 1998 Land Act of the Republic of Uganda). The monies to form part of the Land Fund shall be derived from: monies appropriated by parliament; loans obtained by the government; grants from any donors; any monies paid into the fund under this Act; and any other source approved by the minister in writing in consultation with the minister responsible for finance. Establishment of land fund is essential to rehabilitate those whose land holding right is taken by the action of the government.

On this issue, in the meantime the Ethiopian government has moved one step ahead so as to rehabilitate the life of individuals at the time of compulsory acquisition. The new expropriation of landholdings for public purpose and payment of compensation proclamation No. 1161/2019 that amended proclamation No.455/2005 has gone a good move with regard to establishment of land fund is concerned. The proclamation under article 16 (1) (2) of it obliges the regional states, Addis Ababa and Dire Dawa city administrations in order to establish fund for compensation payment and rehabilitation. The proclamation further obliges the regional states, Addis Ababa and Dire Dawa city administrations in order to develop resettlement packages that may enable displaced people to sustainably resettle. If implemented on the ground, this move has crucial impact so as to protect the life of rural mass at the time of compulsory acquisition of rural land. 
Another great achievement on the land legislation in Uganda that can be a good lesson for Ethiopia is its decentralized system institutional frameworks for the control and management of land. Land administration institutions are arranged starting from the ministry of lands, housing and urban planning to the district land boards. The Land Act of 1998 decentralized land administration to District Land Boards and other district and sub-county structures, namely the District Land Office and Land Registry, the District Land Tribunal and the Sub-County Land Committee. The constitution and land Act in Uganda has assigned land management issues for many sector based organs and these can possibly paves a way for the management of land with the skilled human power. Administering land at the ministry level at the top is also crucial to manage the sector with sufficient budget and human power.

\section{Challenges Impeding Rural Land Governance in Ethiopia}

1) Absence of Comprehensive Rural Land Policy and Separate Land Laws Fitting Each Types of Landholding

Ethiopia has not enacted a document in the name of land policy; rather proclamations have been serving as policy documents. There is no a single documented land policy that clearly sets out the country's land governance. Many African countries (e.g. Kenya, Ghana, Uganda, Tanzania and others) have adopted the comprehensive national land policy which guides the land legislations enacted by the countries. Land policy can serve as a bench mark for other legislations to go through it. Lack of comprehensive land policy in Ethiopia can be taken as one challenge for the effective governance of rural land.

In addition to this, there are no separate legislations that undoubtedly govern rural land issues of every land holding as defined in the land laws. For example, there are no clear and separate laws governing communal and pastoral lands because these holdings by their very nature are different from private and state holdings. There is no separate law that points out how rights on communal lands are registered and certified. Even it is not easy to resolve land related disputes on the pastoral and communal lands because the dispute resolution system hierarchies in the rural land proclamations are seemingly crafted in a manner suitable to resolve disputes that arises in the agricultural lands only. Pastoralists represent some $10 \%-15 \%$ of Ethiopia's population and approximately $40 \%$ of the land area of Ethiopia is considered suitable for pastoral land use only. But in line with the general social and political marginalization of pastoralists in Ethiopia, land tenure issues of pastoral lands have not given much attention. Pastoralists usually retain rather vaguely defined rights of access and use on their landholding. This practice is not conducive to effective management and may lead to encroachment and poor management of such lands. So, it is imperative for the country in order to develop comprehensive rural land policy and separate rural land governing legislations in order to effectively govern the sector in the country. 


\section{2) Lack of Effective Rural Land Administration Institutions}

Existence of strong land administration institutions at the federal and regional states level is essential for the effective implementation of land laws of the country on the ground. Institutional arrangement is an important factor so as to contribute to the success of land administration systems through transforming legal tools and policies into practice. When we see the land administration institutional set up at the federal government's level in Ethiopia, it is arranged at the directorate level under the ministry of agriculture. Land administration \& use directorate under the $\mathrm{MoA}$ is responsible for overseeing land use and land tenure of rural lands outside large scale agricultural investment lands. Since the institution is arranged under the directorate level, then one can believe that it has no sufficient budget and human power in order to administer the country's crucial economic and social asset. It is for this reason that some other African countries (for example, Ghana, Kenya and Uganda) have established the institution at the ministry level in order to scale up the administrative potential of the sector.

The institutional arrangement and capacity of land administration at the regional level is not also as such powerful in order to govern the country's economic and social asset. In theory, every region is autonomous in setting up and staffing its organizational structure. Land administration functions are not handled by a separate and independent agency in most regional states of the country. For instance, environment has been included in the responsibilities of land administration institutions. This is also true for the institutional arrangement at the Zonal and Woreda level arrangements. Making environmental protection part and parcel of land administration institution increase the responsibility of the institution and this paves a way to have weak land administration system in the country.

There are local level institutions established to implement land administration systems, which are called rural Land administration and use committees. The committee members are volunteers who are elected by local community in each kebele to implement the land administration system and work without any payment (Behailu, 2015a). These organs are not experts rather laymen that administer land in the kebele and sub-kebele levels. There are no established guidelines for these organs on how to deal on land issues. There is also no incentive mechanism for these organs for their official duties. It is only Tigray national regional state that established an incentive mechanism (i.e. per diem arrangement) for the committees by a proclamation No. 240/2014 (Article 33 of Tigray Regional State Rural Land Adjudication Committees Proclamation No. 240/2014). Land laws have not also arranged mechanisms for these organs to be supported by experts while conducting their duties. It is only Amhara national regional state which is extended its office even to the kebele level and assigned experts in order to provide technical assistance for the committees (Behailu, 2015a). What we can deduce from all these stipulations is that, since the committees are lay- 
men and are not supported by other experts, it is not easy for them to administer rural lands of their community. Lack of guidelines concerning land governance and none-incentive arrangement in most of the regional states also discourages their vigor and motivation of the committees on the land governance.

\section{3) Lack of Transparency and Public Participation}

Making the public to take part at the time of crafting rural land laws and other issues like participating the public at the time of leasing land to the investors creates acceptance on the part of the general public on the land laws in general and the project of the investors in particular. In Ethiopia, most of the legislations that govern land administration are crafted without getting the blessings of the general public, the NGOs, civil society organizations and other concerned stakeholders. There is also lack of transparency in the allocation of public land. Lack of transparency of tendering process of leaseholds land waives the sense of belongingness of the project of the investors on the part of the public. Ethiopia's commercial leasing process to foreign investors has been highly criticized for lacking transparency and public participation. It is argued that the leasing process does not adequately consult with stakeholders and current users of the land and the terms of the leases are not transparent. For these reasons, largescale agricultural projects in Ethiopia are not being used as intended by the government.

4) Lack of Standardized Valuation and Compensation Methods on One Hand and Valuation and Compensation Experts on the Other

Existence of standardized valuation and compensation methods during expropriation of rural lands are essential to enhance and boost tenure security of land holders on one hand and to rehabilitate the life of individuals whose land has been taken for more public purpose. Repeatedly hearing complain on the inadequacy of amount of compensation paid for land taken under the power of eminent domain in Ethiopia is not strange. Land taking by regional governments for expansion of cities and towns and for lease to investors in agriculture and industry is rising rapidly in Ethiopia (Solomon, 1994). But lack of standardized valuation and compensation methods and procedures are causing different valuations by different land taking agencies, resulting in different compensation values for similar lands. This is also evicting smallholder farmers and pastoralists from their holding without receiving just and prompt compensation during an expropriation of their landholding.

On the other line, Valuation and compensation experts are essential in order to adequately compensate land holders at the time of compulsory acquisition of land. Existence of compensation valuation experts can pave a way for land holders in order to get adequate amount of compensation. In Ethiopia, there are no experts that work on determining valuation of compensation during compulsory acquisition of rural land. Lack of compensation valuation experts in Ethiopia is one reason for the continual existence of complains on the inadequacy of amount of compensation on the side of landholders. Ethiopia can draw a good 
lesson from other African countries so as to establish land valuation experts. For example, Ghana has established a separate land board that work on all matters of compensation for land acquired by the government or any of its agencies; preparing valuation lists for property rating purposes; and valuation of interests in land, including all customary land.

\section{5) Large Scale Land Deals or Land Grabbing}

The practice of land grabbing or large-scale land transfer in Ethiopia is criticized by displacing local communities on one hand and undermining their livelihoods and food security on the other. Studies confirm that, large-scale agricultural investment is implemented in a manner of excluding local populations and harming the environment (Tura, 2017). Moreover, in Ethiopia federal government has leased out the large tracts of land to private investors by taking over the constitutional mandate of regional states regarding administration of land and other natural resources that is stipulated under article 52 (2) (d) of the FDRE Constitution. It is Ministry of Agriculture which is authorized to administer any large-scale land deals in the country where the land size is more than five thousand hectares. Accordingly, regional states are not allowed to conduct land deals with local or foreign investor where the land size meant for investment is more than five thousand hectare even if the project is being executed within their respective jurisdictions. The mandate that given for the federal ministry of agriculture on regional lands is against constitutional stipulation that authorizes regional states to administer land and other natural resources in accordance with federal laws within their respective regions and this possibly creates overlap of functions between the tiers of government on the governance of rural land is concerned.

\section{Concluding Remarks}

The Ethiopian legal and institutional frameworks governing rural land in relation with other African countries exhibit many gaps that the Ethiopian legal system should have to respond in order to have effective land governance. Many African countries have adopted comprehensive national land policies which guide the land legislations enacted by the countries. Among others; Ghana, Kenya and Uganda have comprehensive national land policy that can be a source for any other specific legislation. Nevertheless, land is a livelihood for more than $80 \%$ of the Ethiopians population; there is no comprehensive national land policy that guides the development of the sector rather the land administration proclamations are serving as a policy framework. Another distinguishing feature of land governance system in Ghanaian, Kenyan and Ugandans in addition to formulation of national land policy is the adoption of dual (i.e. customary and statutory) land tenure systems. The land legislations in these countries have given sufficient room for the protection of customary land rights and the rights in customary holdings are equally compensated even at the time of compulsory acquisition of their holding. When we see the constitution of Kenya, community 
land shall not be disposed of or otherwise used except in terms of legislation specifying the nature and extent of the rights of members of each community individually and collectively (Article 63 (4) of 2010 Constitution of the Republic of Kenya). Likewise, the constitution and the Land Act in Uganda also give similar protection for customary holdings and provide citizens owning land under customary tenure to acquire certificates of ownership; and even land under customary tenure may be converted to freehold land ownership by registration (Article 237 (4) (a) (b) of 1995 Constitution of the Republic of Uganda; Section 9 of 1998 Land Act of the Republic of Uganda).

Another innovative approach that Ethiopia can grasp from the above countries is the protection accorded for the land by giving it a market value especially at the time of compulsory acquisition. Land legislations for example, in Ghana and Kenya compensate owners not only for the value of the produce upon their land but also for the market value of the land taken, cost of disturbance and other damage like severance and injurious affection when rural land holding is acquired for greater public purpose. The 1998 Land Act in Uganda also provides that, any compulsory acquisition of land shall be paid at a fair market valuation assessed on a willing seller willing buyer basis. The Act also obliges the state to furnish compensation for any losses caused by severance or injurious affection and reasonable costs of disturbance.

Institutional arrangements governing rural land administration are also well established in Ghana, Kenya and Uganda. The mandate to administer land is arranged at the ministry level at the top and there is also other separate middle and lower level sector based institutions that administer land issues solitarily. For example in Kenya, under the ministry of Land there are sector based institutions like National Land Commission, District Land Boards, and Community Land Boards governing each sector of land. Uganda also decentralized land administration to District Land Boards and other district and sub-county structures, namely the District Land Office and Land Registry, the District Land Tribunal and the Sub-County Land Committee. Ethiopia that governs land at the directorate level under the ministry of agriculture at the top and bureau of land and environmental protection at the middle and land and environmental protection departments at the lower level can craft this good practice from Ghana, Kenya and Uganda in order to have effective rural land governance in the country.

\section{Conflicts of Interest}

The author declares no conflicts of interest regarding the publication of this paper.

\section{References}

Antwi, A., \& Adams, J. (2003). Rent-Seeking Behavior and Its Economic Costs in Urban Land Transactions in Accra, Ghana. Urban Studies, 40, 2083-2098.

https://doi.org/10.1080/0042098032000116121 
Aredo, D. (1999). The Role of Women in Rural Development in Ethiopia (pp. 329-353).

Behailu, D. (2015a). Transfer of Land Rights in Ethiopia: Towards a Sustainable Policy Framework. Hague: Eleven International Publishing.

Behailu, D. (2015b). Large-Scale Land Acquisitions in Ethiopia: Towards Attracting Foreign Direct Investment. Journal of Land Administration in Eastern Africa, 3, 279-295.

Bruce, W. J. et al. (1994). After the derg: An Assessment of Rural Land Tenure Issue in Ethiopia. Addis Ababa: Institute of Development, Research and Land Tenure Center.

Deininger, K., \& Jin, S. (2005). The Potential of Land Markets in the Process of Economic Development: Evidence from China. Journal of Development Economics, 78, 241-270. https://doi.org/10.1016/j.jdeveco.2004.08.002

Devereux, S. et al. (2005). Too Much Inequality or Too Little? Inequality and Stagnation in Ethiopia. IDS Bulletin, 36, 121-126. https://doi.org/10.1111/j.1759-5436.2005.tb00208.x

Ege, S. (1994). Land Tenure Issue in Northern Shewa: Tenure Issues in Different Agro Ecologies. In Dessalegn (Ed.), Land Tenure and Land Policy in Ethiopia after the Derg, Proceeding of the Second Workshop of the Land Tenure Project. Trondheim: The University of Trondheim, Center for Environment and Development Unit.

Eide, A. (2006). Promoting Economic, Social and Cultural Rights: Obligations of States and Accountability of Non-State Actors. FAO, Rome, Italy: Electronic Publishing Policy and Support Branch Communication Division, Food and Agriculture Organization of United Nations, Land and Property Rights.

Ethiopian Economic Association, Ethiopian Economic Policy Research Institute, EEA, EEPRI (2002). United Printers, Addis Ababa.

Expropriation of Land Holdings for Public Purposes, Payments of Compensation and Resettlement of Displaced People Proclamation (2019). Proc. No. 1161/2019.

Expropriation of Landholdings for Public Purposes and Payment of Compensation Proclamation (2005). Proc. No. 455/2005.

FAO (Food and Agriculture Organization of the United Nations) (2009). Towards Improved Land Governance. Land Tenure Working Paper 11, by David Palmer et al. in Collaboration with Clarissa Augustinus, Paul Munro-Faure, Mika-Petteri Törhönen, Anni Arial, Rome.

FAO (Food and Agriculture Organization of the United Nations) (2002). Land Tenure and Rural Development. Rome.

FDRE (The Federal Democratic Republic of Ethiopia) Constitution (1995). Proclamation No. $1 / 1995$.

Future Agricultures (2014). Kenya's Land Reform Agenda: Pastoralism within the Current Land Debate, Policy Brief.

Gebremedhin, B., \& Nega, B. (2005). Land and Land Policy in Ethiopia in the Eyes of Ethiopian Farmers: An Empirical Investigation. In Proceedings of the Second International Conference on the Ethiopian Economy (Vol. 2). Addis Ababa: Ethiopian Economic Association.

Hailu, Z. (2016). Land Governance Assessment Framework Implementation in Ethiopia. Country Report, World Bank.

Hardin, G. (1968). The Tragedy of the Commons. Science, 162, 1243-1248. https://doi.org/10.1126/science.162.3859.1243

Hobben, A. (2002). Ethiopian Land Tenure Revisited: Continuity, Change and Contradictions. In Workneh et al. (Eds.), Current Issue Issues on Land Tenure in Ethiopia: 
Access, Food Production and Natural Resource Management, Proceedings on the Workshop on Current Issues on Land Tenure in Ethiopia. Addis Ababa: Institute of Development Research, Addis Ababa University.

Inter-Africa Group (1992). Final Report of the Symposium on Rehabilitating the Ethiopian Economy, 15-18 January 1992, Addis Ababa.

Kassahun, D. (2006). Towards the Development of Land Taxation in Ethiopia. In Attilo et al. (Eds.), Ethiopia: Politics, Policy Making and Rural Development. Addis Ababa: Addis Ababa University Press.

Kenya Gazette Supplement Acts, Community Land Act (2016). Nairobi, 7th September, 2016.

Ministry of Land (2009). Kenya National Land Policy. Nairobi.

Minutes of the Ethiopian Constituent Assembly (1995). Volume 4, Addis Ababa.

MOIPAD (Ministry of Information, Press and Audiovisual Department) (2001). Federal Democratic Republic of Ethiopia, Rural Development Policies, Strategies and Instruments (Amharic). Addis Ababa.

Narh, P. et al. (2016). Land Sector Reforms in Ghana, Kenya and Vietnam: A Comparative Analysis of Their Effectiveness. Basel, MDPI.

Olika, T. (2006). Ethiopia: Politics of Land Tenure under Three Regimes: A Carrot and Stick Ruling Strategy. In K. Alexander, \& Yonas (Eds.), Ethiopia Politics, Policy Making and Rural Development. Addis Ababa University Press.

Place, et al. (1993). Land Tenure Security and Agricultural Performance in Africa: Overview of Research Methodology. In J. Bruce, \& S. E. Migot-Adholla (Eds.), Searching for Land Tenure Security in Africa (pp. 15-40). Dubuque: Kendall/Hunt Publishers.

Proclamation to Amend Proc. No. 56/2002, 70/2003 and 103/2005 of Oromia Rural Land Administration and Use Proclamations, Proclamation No. 130/2007.

Proclamation to Provide for the Establishment of the Oromia Bureau of Rural Land and Environmental Protection (2009). Proclamation No. 147/2009.

Proclamation to Provide Power and Duties of Rural Kebele Land Adjudication Committee of Tigray National Regional State (2014). Proclamation No. 240/2014.

Rahmato, D. (1992). The Land Question and Reform Policy: Issues for Debate. Dialogue, 1, 43-57.

Rahmato, D. (1994). Land Policy in Ethiopia at Cross-Roads. In Dessalegn (Ed.), Land Tenure and Land Policy in Ethiopia after the Derg. Trondheim: Reprocentralen AVH.

Schlager, E., \& Ostrom, E. (1992). Property-Rights Regimes and Natural Resources: A Conceptual Analysis. Land Economics, 69, 249-262. https://doi.org/10.2307/3146375

SNNPRS (Southern Nations, Nationalities and People's Regional State) Environmental Protection, Land Administration and Utilization Authority Establishment Proclamation (2003). Proclamation No. 52/2003.

SNNPRS (Southern Nations, Nationalities and People's Regional State) Rural Land Administration and Use Proclamation (2007). Proclamation No. 110/2007.

Solomon, G. (1994). Urban Land Issues and Policies in Ethiopia. In D. Rahmato (Ed.), Land Tenure and Land Policy in Ethiopia after the Derg, Proceedings of the Second Workshop of the Land Tenure Project. Trondheim: University of Trondheim.

The Administration of Lands Act of the Republic of Ghana, Act No. 123 (1962).

The Amhara National Regional State Executive Organs Re-Establishment and Determination of Their Powers and Duties Proclamation (2010). Proclamation No. 176/2010. 
The Constitution of the Republic of Ghana (1992).

The Constitution of the Republic of Kenya (2010).

The Constitution of the Republic of Uganda (1995).

The Federal Rural Land Administration and Use Proclamation (2005). Proclamation No. 456/2005.

The Land Act of the Republic of Uganda (1998).

The National Land Commission Act of Kenya (2012). Act No. 5 of 2012.

The Revised Amhara National Regional State Rural Land Administration and Use Proclamation (2006). Proclamation No. 133/2006.

The Revised Constitution of the Amhara National Regional State (2001). Proclamation No. 59/2001, Bahirdar, 5th November 2001.

The Revised Tigray National Regional State Rural Land Administration and Use Regulation (2014). Regulation No. 85/2014.

The Revised Tigray National Regional State Rural Land Administration and Use Proclamation (2014). Proclamation No. 239/2014.

The Somali National Regional State Rural Land Administration and Use Proclamation (2013). Proc. No. 128/2013.

Tiah, J. B. (2013). Issues and Options for Improved Land Sector Governance in Ghana: Application of the Land Governance Assessment Framework, Synthesis Report.

Tura, H. A. (2017). Linking Land Rights and the Right to Adequate Food in Ethiopia: Normative and Implementation Gaps. Nordic Journal of Human Rights, 35, 85-105. https://doi.org/10.1080/18918131.2017.1312860

USAID (United States Agency for International Development) (2004). Ethiopia Land Policy and Administration Assessment Final Report. Burlington, VT 05401 USA.

Wily, A. L., \& Hammond, N. A. D. (2001). Land Security and the Poor in Ghana: Is There a Way Forward? DFID Ghana Rural Livelihoods Program.

Woldemariam, M. (1999). Meretna Limat Be Ethiopia: Economic Focus, Vol. 12, No. 4, August, EEA. (In Amharic) 